\title{
KAJIAN TEKNOLOGI JAJAR LEGOWO SUPER DALAM MENDUKUNG PENINGKATAN PRODUKSI PADI
}

\author{
Jajar Legowo Super Technology of Study in Supporting Rice Production \\ Yati Haryati* dan Liferdi \\ BPTP Jawa Barat \\ Jl. Kayuambon No. 80, Lembang-Bandung Barat \\ Alamat Korespondensi: dotyhry@yahoo.com
}

\begin{abstract}
ABSTRAK
Penggunaan varietas unggul merupakan salah satu metode perbaikan teknis budidaya yang sangat erat kaitannya dengan peningkatan produktivitas padi sawah. Kegiatan Kajian Varietas Unggul Baru Inpari 30 dilaksanakan di Kelompok Tani Dalima, Kelurahan Situgede, Kec. Bogor Barat, Kota Bogor. Kegiatan dilaksanakan dengan menerapkan rekomendasi teknologi dan cara petani pada lahan sawah milik petani dengan petakan alami. Tujuan penelitian untuk mengetahui adaptasi VUB Inpari 30 dan rekomendasi teknologi di wilyah Kota Bogor. Peubah yang diamati yaitu: Tinggi tanaman (30, 60 dan 90 HST), komponen hasil (jumlah gabah isi per malai dan jumlah gabah hampa per malai dan produktivitas). Data dianalisis dengan Uji t test. Analisis menggunakan SPSS versi 20 for windows. Hasil penelitian menunjukkan bahwa Teknologi Jajar Legowo Super dengan menggunakan Varietas Unggul Baru (VUB) Inpari 30 mencapai produktiviats sebesar 7,60 t ha-1.
\end{abstract}

Kata kunci : Varietas Unggul Baru, Jajar legowo super

\section{ABSTRACT}

The use of improved varieties of the methods of cultivation technical improvement that is closely related to the increase of rice field productivity. Assessment of new superior varieties Inpari 30 was conducted at Dalima Farmer Group, Situgede Village, Sub District Bogor Barat, Bogor City. Activities are implemented by applying technology recommendations and farmers fields. This research is to adaptation of New Superior Varieties Inpari 30 and the recommendation of technology in Bogor City. The observed variables were: Plant Height (30, 60 and 90 Day After Planting), yield component (number of grain fill per panicle and number of empty grain per panicle and productivity). The data were analyzed by $t$ test. Analysis using SPSS version 20 for windows. The results showed that Jajar Legowo Super Technology using New Superior Varieties Inpari 30 achieved productivity of 7,60 tha $\mathrm{ha}^{-1}$.

Key words: New Superior Variety, Jajar legowo super

\section{PENDAHULUAN}

Varietas unggul memberikan manfaat teknis dan ekonomis yang banyak bagi perkembangan suatu usaha pertanian, diantaranya pertumbuhan tanaman menjadi seragam sehingga panen menjadi serempak, rendemen lebih tinggi, mutu hasil lebih tinggi dan sesuai dengan selera konsumen, dan tanaman akan mempunyai ketahanan yang tinggi terhadap gangguan hama dan penyakit dan beradaptasi yang tinggi terhadap lingkungan (Manrapi dan Ratule, 2010).

Penggunaan varietas unggul merupakan salah satu metode perbaikan teknis budidaya yang sangat erat kaitannya dengan peningkatan produktivitas padi sawah. Badan Penelitian dan Pengembangan Pertanian berhasil menciptakan varietas padi yang responsif terhadap perubahan iklim dan cekaman lingkungan ekstrim. Salah satu varietas 
unggul baru (VUB) tersebut yaitu Inpari 30, di mana kelebihannya tahan terhadap rendaman sehingga diharapkan dapat menunjang produksi yang tinggi dengan keadaan perubahan iklim yang ekstrim terutama resiko akibat banjir dan genangan.

Pada tahun 2012 Badan Penelitian dan Pengembangan Pertanian (Balitbangtan) telah melepas varietas unggul baru (VUB) dengan nama Inpari 30 dengan salah satu kelebihannya tahan terhadap rendaman, sehingga diharapkan dapat menunjang produksi yang tinggi dengan keadaan perubahan iklim yang ekstrim terutama resiko akibat banjir dan genangan. Inpari 30 cocok ditanam di lahan sawah dataran rendah sampai ketinggian $400 \mathrm{~m}$ dpl di daerah luapan sungai, cekungan dan rawan banjir lainnya dengan rendaman keseluruhan fase vegetatif selama 15 hari. Umur tanaman Inpari 30111 hari setelah semai dengan potensi hasil 9,6 $\mathrm{tha}^{-}$ 1. Dilihat dari tingkat ketahanannya terhadap hama dan penyakit, varietas ini tergolong agak rentan wereng batang coklat biotipe 1 dan 2 serta rentan terhadap biotipe 3, agak rentan terhadap hawar daun bakteri patotipe III, serta rentan terhadap patotipe IV dan VIII (Pusat Penelitian dan Pengembangan Tanaman Pangan, 2016).

Untuk mendukung peningkatan produksi dan produktivitas selain menggunakan Varietas Unggul Baru (VUB) juga perlu menerapkan komponen teknologi yang sinergi, salah satunya Teknologi jajar Legowo Super. Teknologi jajar legowo super merupakan rekomendasi teknologi yang terdiri dari: 1) Penggunaan Varietas Unggul Baru (VUB), potensi hasil tinggi (Spek-lok), 2) Biodekomposer saat pengolahan tanah, 3) Pupuk Hayati, serta pemupukan berimbang berdasarkan status hara tanah, 4) Pengendalian OPT dengan pestisida nabati dan pestisida anorganik berdasarkan ambang kendali dan 6) Penggunaan Alsintan (transplanter dan combine harvester).

Keberhasilan penerapan teknologi dalam budidaya padi dapat dicapai dengan integrasi secara tepat berbagai teknologi yang saling mendukung. Dalam perkembangannya, sistem tanam legowo merupakan dasar teknologi budidaya padi yang dapat menghasilkan produksi optimal. Namun demikian, aspek pemupukan, varietas unggul, pengendalian OPT, serta penggunaan alsintan secara terintegrasi tentu akan menyempurnakan budidaya padi legowo tersebut (Husnain et al., 2016).

Dalam penerapan teknologi jarwo super menggunakan cara tanam sistem legowo 2:1. Cara tanam sistem legowo merupakan salah satu komponen teknologi yang dapat meningkatkan produktivitas padi. Hal ini dapat diperoleh karena populasi tanaman bertambah sekitar 20$25 \%$ dibandingkan dengan sistem tanam 
biasa (tegel). Pada prinsipnya dapat meningkatkan populasi dengan cara mengatur jarak tanam (Wacim dan Dani, 2016). Dengan sistem tanam ini, mampu memberikan sirkulasi udara dan pemanfaatan sinar matahari lebih baik untuk pertanaman. Selain itu, upaya penanggulangan gulma dan pemupukan dapat dilakukan dengan lebih mudah (Badan Penelitian dan Pengembangan Pertanian, 2013).

Pengembangan Inovasi Teknologi Jajar Legowo Super untuk mengantisipasi menyusutnya lahan pertanian, sementara permintaan terus meningkat. Bila inovasi ini dikembangkan di $20 \%$ dari total lahan pertanian irigasi saja, maka dapat menyumbang kenaikan produksi 3,84 juta ton Gabah Kering Giling (GKG) pertahun (Badan Penelitian dan Pengembangan Pertanian, 2016). Oleh karena itu untuk perlu dilakukan kajian di wilayah yang mempunyai areal sawah yang terbatas (wilayah perkotaan) mengenai penerapan teknologi jajar legowo super dalam upaya peningkatan produktivitas untuk mencapai target produksi padi secara nasional.

\section{METODE PENELITIAN}

Kegiatan dilaksanakan di Kelompok Tani Dalima, Kelurahan Situgede, Kec. Bogor Barat, Kota Bogor. Varietas yang digunakan Inpari 30 dengan menerapkan rekomendasi teknologi dan cara petani dengan 3 ulangan dan masing-masing ulangan terdiri dari 30 sampel tanaman.

Perlakuan A yaitu: Rekomendasi teknologi yaitu: 1) Menggunakan Varietas Unggul Baru (VUB) Inpari 30, 2) Biodekomposer pada saat pengolahan tanah dengan disemprotkan pada jerami pada saat pengolahan pertama yaitu $2 \mathrm{~kg} / \mathrm{ha}$ dengan dilarutkan pada 400 liter air, 3) Pupuk hayati, diaplikasikan pada saat seed treatment dengan dosis $500 \mathrm{~g} / 25 \mathrm{~kg}$ benih, 4) Pengendalian hama dan penyakit menggunakan pestisida nabati, 5) Menggunakan pupuk organik dengan dosis $1000 \mathrm{~kg} / \mathrm{ha}$, 6) pupuk anorganik berdasarkan status hara tanah dengan menggunakan Perangkat Uji Tanah Sawah (PUTS) dengan dosis: NPK Phonska $300 \mathrm{~kg}$ dan Urea 100 kg/ha, dan 7) Cara tanam sistem jajar legowo $2: 1(50 \times 25 \times 12,5$ $\mathrm{cm}$ ) dan perlakuan B (cara petani) yaitu: 1) Menggunakan Varietas Unggul Baru (VUB) Inpari 30, 2) Menggunakan cara tanam jajar legowo $4: 1,3)$ Pemupukan dengan dosis pupuk: NPK Phonska 400 dan 200 urea kg/ha, dan 5) Pengendalian hama/penyakit menggunakan pestisida kimia. Data yang diamati yaitu: Tinggi tanaman (30,60 dan 90 HST), komponen hasil (jumlah gabah isi per malai dan jumlah gabah hampa per malai dan produktivitas). Data dianalisis dengan Uji $\mathrm{t}$ kemudian dilakukan Analisis menggunakan SPSS versi 20 for windows. 


\section{HASIL DAN PEMBAHASAN}

\section{Keragaan Agronomis}

Penerapan rekomendasi teknologi berpengaruh terhadap pertumbuhan tinggi tanaman padi Varietas Inpari 30 pada umur 60 dan 90 HST dan jumlah anakan pada umur 30, 60 dan 90 HST. Sedangkan tinggi tanaman pada umur 30 HST cara petani lebih tinggi dibandingkan rekomendasi teknologi. Hal ini diduga pada saat awal tanam kondisi tanaman masih beradaptasi dengan kondisi lingkungan sehingga pertumbuhan tanaman belum optimal. Tinggi rendahnya batang tanaman padi dipengaruhi oleh sifat atau ciri yang mempengaruhi daya hasil varietas (Suprihatno, 2010).

Jumlah anakan dengan menerapkan rekomendasi teknologi lebih tinggi, hal ini menunjukkan bahwa dengan dosis pupuk berdasarkan Perangkat Uji Tanah Sawah (PUTS) dan cara tanam sistem legowo $2: 1$ memberikan jumlah anakan yang lebih banyak. Faktor yang berpengaruh terhadap hasil gabah adalah jumlah anakan produktif dan jumlah malai yang terbentuk. Semakin banyak anakan produktif yang menghasilkan malai maka semakin banyak pula gabah yang dihasilkan (Sitinjak dan Idwar, 2015).

Penerapan cara tanam sistem jajar legowo memberikan sirkulasi udara, pemasukan cahaya dan aliran air serta penyerapan unsur hara yang lebih merata sehingga berpengaruh terhadap pertumbuhan tanaman (Azwir, 2007). Jumlah anakan yang banyak berpengaruh terhadap jumlah daun yang berdampak pada peningkatan luas daun sehingga mengakibatkan penyerapan cahaya matahari lebih besar yang pada gilirannya berpengaruh terhadap jumlah anakan produktif. Hal ini berkontribusi terhadap penambahan hasil fotosintesis yang akan berpengaruh terhadap produksi (Suhartatik et al., 2011). Hasil penelitian Sutaryo (2015), jumlah anakan produktif Varietas Inpari 30 cukup banyak (20,50 batang) disebabkan oleh jumlah bibit 1-2 batang per lubang. Jarak tanam merupakan salah satu cara untuk menciptakan lingkungan dan unsur hara dapat tersedia secara merata bagi setiap tanaman (Kurniawan et al., 2016).

Aplikasi dosis pupuk sesuai rekomendasi berdasarkan perangkat uji tanah sawah (PUTS) berdampak pada Tabel 1. Tinggi tanaman dan jumlah anakan Inpari 30 dengan teknologi budidaya yang berbeda

\begin{tabular}{lcccccc}
\hline \multirow{2}{*}{ Perlakuan } & \multicolumn{2}{c}{ Tinggi Tanaman (HST) cm } & \multicolumn{3}{c}{ Jumlah Anakan (batang) } \\
\cline { 2 - 7 } & 30 & 60 & 90 & 30 & 60 & 90 \\
\cline { 2 - 7 } Rekomendasi teknologi & $35,63 \mathrm{~b}$ & $101,16 \mathrm{a}$ & $102,14 \mathrm{a}$ & $11,26 \mathrm{a}$ & $18,70 \mathrm{a}$ & $15,93 \mathrm{a}$ \\
\hline Cara Petani & $36,03 \mathrm{a}$ & $91,00 \mathrm{~b}$ & $91,80 \mathrm{~b}$ & $6,33 \mathrm{~b}$ & $11,90 \mathrm{~b}$ & $10,90 \mathrm{~b}$ \\
\hline
\end{tabular}

Keterangan: Angka yang sama pada kolom yang sama tidak menunjukkan beda nyata pada taraf 5\% Uji DMRT. 
Tabel 2. Komponen hasil dan hasil Inpari 30 dengan teknologi budidaya yang berbeda

\begin{tabular}{lccc}
\hline \multicolumn{1}{c}{ Perlakuan } & $\begin{array}{c}\text { Jumlah gabah isi } \\
\text { per malai }\end{array}$ & $\begin{array}{c}\text { Jumlah gabah } \\
\text { hampa per malai }\end{array}$ & $\begin{array}{c}\text { Produktivitas GKP } \\
(\mathrm{t} / \mathrm{ha})\end{array}$ \\
\hline Rekomendasi teknologi & $172,97 \mathrm{a}$ & $10,07 \mathrm{~b}$ & $7,60 \mathrm{a}$ \\
\hline Cara Petani & $158,93 \mathrm{~b}$ & $15,77 \mathrm{a}$ & $6,60 \mathrm{~b}$ \\
\hline
\end{tabular}

Keterangan: Angka yang sama pada kolom yang sama tidak menunjukkan beda nyata pada taraf $5 \%$ Uji DMRT.

pertumbuhan tanaman padi Inpari 30

dengan optimal. Hal ini sejalan dengan hasil

penelitian Husnain et al., (2016), bahwa

pemberian pupuk harus dilakukan secara berimbang sesuai dengan kebutuhan tanaman dan status hara tanah. Kebutuhan tersebut harus menyesuaikan dengan target hasil terkait penggunaan varietas dengan hasil tinggi. Hal ini berkaitan dengan ketersediaan hara yang ada dalam tanah sehingga produksi Varietas Inpari 30. Sedangkan ketersediaan bahan organik di dalam tanah dapat mencegah kahat unsur hara mikro, meningkatkan kapasitas tukar kation (KTK), dan dapat membentuk senyawa komplek dengan ion logam yang meracuni tanaman seperti $\mathrm{Al}, \mathrm{Fe}$, dan $\mathrm{Mn}$ (Suriadikarta dan Simanungkalit, 2010).

\section{Komponen Hasil}

Varietas Inpari 30 dengan menerapkan rekomendasi teknologi jajar legowo super menunjukkan jumlah gabah isi per malai dan produktivitas lebih tinggi dibandingkan dengan cara petani. Penanaman dengan menggunakan cara tanam jajar legowo dapat mengoptimalkan ruang, cahaya, air, dan nutrisi bagi tanaman padi sehingga meningkatkan source, kekuatan sink, dan jumlah anakan produktif.

Jarak tanam yang tidak terlalu rapat menyebabkan sinar matahari masuk ke dalam areal pertanaman yang selanjutnya dapat digunakan oleh tanaman untuk proses fotosintesis. Semakin banyak tanaman menyerap cahaya matahari akan mempercepat terjadinya proses fotosintesis, serta pembentukan fotosintat sehingga pengisian gabah akan optimal (Supriyanto et al., 2010).

Produktivitas tanaman dipengaruhi oleh faktor genetik dan lingkungan. Lingkungan dapat berperan menentukan tinggi rendahnya gabah isi. Keadaan cuaca yang cerah dapat meningkatkan laju fotosintesis yang berhubungan dengan intensitas cahaya matahari yang diserap. Fotosintat yang dihasilkan akan disimpan dalam jaringan batang dan daun yang akan ditranslokasikan ke gabah pada tingkat kemasakan. Semakin banyak fotosintat yang diangkut ke malai cukup untuk pengisian gabah, maka persentase gabah isi akan naik. Akan tetapi jika fotosintat tidak cukup untuk mengisi semua gabah yang ada di malai, maka gaba isi per malai akan 
rendah, hal ini dipengaruhi juga oleh jumlah anakan produktif (jumlah malai per rumpun) yang dihasilkan (Sugiono dan Saputro, 2016).

Kondisi lingkungan tumbuh yang sesuai cenderung merangsang proses inisiasi malai menjadi sempurna, sehingga berpeluang terbentuknya lebih banyak bakal gabah. Namun demikian semakin banyak gabah yang terbentuk, meningkatkan beban tanaman untuk membentuk gabah bernas. Apabila saat proses pengisian gabah, tidak diimbangi dengan ketersediaan hara yang mencukupi akan banyak terbentuk gabah hampa. Persentase gabah isi merupakan salah satu indikator produktivitas tanaman, semakin tinggi persentase gabah isi yang diperoleh suatu varietas menandakan varietas tersebut mempunyai produktivitas yang tinggi (Mahmud dan Purnomo, 2014). Kebernasan gabah dipengaruhi oleh hasil asimilasi sebelum pembuahan dan hasil asimilasi yang dihasilkan sesudah pemasakan (Mungara et al., 2013). Komponen bobot 1000 butir gabah merupakan salah satu faktor penting untuk memprediksi potensi hasil tanaman. Semakin tinggi bobot gabah menunjukkan semakin bernas gabah tersebut. Gabah berkualitas identik dengan gabah bernas. Bobot gabah yang tinggi berarti menunjukkan kualitas suatu varietas (Thamrin et al., 2012).

\section{KESIMPULAN}

Teknologi Jajar Legowo Super dengan menggunakan Varietas Unggul Baru (VUB) Inpari 30 mencapai produktiviats sebesar 7,60 $\mathrm{t} \mathrm{ha}^{-1}$ dengan peningkatan $15 \%$ dibandingkan cara budidya petani.

\section{DAFTAR PUSTAKA}

Azwir. 2007. Sistem tanam legowo dan pemberian $p$-stater pada padi sawah dataran tinggi. Jurnal Akta Agrosia, 11(2): 102 - 107.

Badan Penelitian dan Pengembangan Pertanian. 2013. Panduan Sistem Tanam Legowo. Badan Litbang Pertanian, Kementerian Pertanian, Indonesia.

Badan Penelitian dan Pengembangan Pertanian. 2016. Teknologi jajar legowo super untuk mendongkrak produktivitas padi. http://www. litbang.pertanian.go.id/berita/one/25 74/ diakses tanggal 21 Desember 2017.

Husnain, Nursyamsi, D., Syakir, M. 2016. Teknologi Pemupukan Mendukung Jarwo Super. Jurnal Sumberdaya Lahan, 10 (1) : 1 - 10.

Kurniawan, R., Harti, A., O., R., dan Cartika, K. 2016. Pertumbuhan dan hasil padi (Oryza sativa L.) kultivar inpari 30 akibat pemberian berbagai mikroorganisme lokal pada sistem tanam yang berbeda. Jurnal Ilmu Pertanian dan Peternakan, 4(2): 230238.

Manrapi, A. dan Taufiq Ratule, M., T. 2010. Keragaan Hasil Beberapa Varietas Unggul Baru (VUB) Padi Sawah Irigasi dalam Kegiatan Perbanyakan Benih Mendukung SLPTT Padi di Sulawesi Tenggara. Prosiding Pekan Serealia Nasional. Hal 486-489. 
Mahmud, Y dan Purnomo SS. 2014. Keragaman Agronomis beberapa varietas unggul baru tanaman padi (Oryza sativa L.) pada model pengelolaan tanaman terpadu. Jurnal Ilmiah Solusi, 1(1): 1-10.

Mungara E, Indradewa D, Rogomulyo R. 2013. Analisis pertumbuhan dan hasil padi sawah (Oryza sativa 1.) pada sistem pertanian konvensional, transisi organik, dan organik. Vegetalika, 2(3): 1-12.

Pusat Penelitian dan Pengembangan Tanaman Pangan. 2016. Deskripsi Tanaman Padi. Pusat Penelitian dan Pengembangan Tanaman Pangan. Kementerian Pertanian.

Sitinjak, H., dan Idwar. 2015. Respon berbagai varietas padi (Oryza sativa L.) yang ditanam dengan pendekatan teknik budidaya jajar legowo dan sistem tegel. Jurnal Online Mahasiwa Fakultas Pertanian Universitas Riau, 2(2): 1 - 15.

Sugiono, D dan Saputro, NW. 2016. Respon pertumbuhan dan hasil beberapa genotip padi (Oryza sativa L.) pada berbagai sistem tanam. Jurnal Agrotek Indonesia, 1 (2): 105-114.

Suhartatik E, Makarim A., K., dan Ikwani. 2011. Respon lima varietas unggul baru terhadap perubahan jarak tanam. Prosiding Seminar Nasional Hasil Penelitian Padi 2011. Buku 3: Inovasi Teknologi Padi Mengantisipasi Cekaman
Lingkungan Biotik dan Abiotik. Hal 1259 - 1273.

Suprihatno, B. 2010. Deskripsi Varietas Padi. Balai Besar Penelitian Tanaman Padi, Badan Penelitian dan Pengembangan Pertanian, Subang.

Supriyanto E., E Syakiroh J., dan Wisnu A. 2010. pengaruh sistem tanam legowo dan konsentrasi pupuk pelengkap cair terhadap pertumbuhan dan produksi padi. Biofarm Jurnal Ilmiah Pertanian, 13(8).

Suriadikarta, DD dan Simanungkalit R., D., M. 2010. Pupuk Kandang. Eds, Pupuk Hayati dan Pupuk Organik. Editor, R.D.M Simanungkalit, Didi Ardi Suriadikarta, Rasti Saraswati, Diah Setyorini, dan Wiwik Hartatik. Balai Pustaka, Jakarta.

Sutaryo, B. 2015. Respon 15 varietas unggul baru padi terhadap tujuh metode tanam untuk hasil dan komponen hasil. Jurnal Agrin, 19(1): $8-21$.

Thamrin, T. Marpaung, I. S. \& Syahri. 2012. Produktivitas dan ketahanan galur harapan padi terhadap penyakit tungro di Sumatera Selatan. Jurnal Lahan Suboptimal, 1(2): 130-137.

Wacim dan Dani, U. 2016. Modifikasi jarak tanam legowo dua terhadap pertumbuhan, komponen hasil dan hasil tanaman padi (Oryza sativa L.) kultivar Inpari 30. Agrivet Journal, 4 (2): 286-294. 